\title{
Influence of Social Studies Students' Self Perception on Their Academic Performance in Calabar Education Zone Cross River State
}

\author{
Edinyang Sunday David, Ushie Doris Emmanuel, Urubulam Cecillia
}

\begin{abstract}
This study explored the effect of students' self-perception of social studies on their academic performance in Calabar Cross River State Educational Region, Nigeria. The method of descriptional analysis was used. 500 Students in social studies were randomly chosen from the six Local Government sampled schools that make up the district. A 20 item questionnaire was developed and used for data collection with an adjusted four-point Likert scale. Statistical analysis was carried out on the data collected using descriptive statistics to address the study questions. The study showed that there is a substantial relationship between the self-perception and academic success of social studies students. It was proposed that teachers should develop positive attitudes towards students on their own, and as such, promote active involvement in classroom instruction.
\end{abstract}

Index Terms - Self-perception, academic Performance, social studies, self-concept, Students.

\section{INTRODUCTION}

Since social studies were introduced as a school subject into the Nigerian educational system in 1963, only at the end of the 1970s was some focused effort made to emphasize its aim with necessary ingredients better to meet the main national educational objectives. Social studies have been developed as a fruitful direction for the achievement of the Nigerian educational goals. It is due to this fact that it is granted pride of position in the national policy on education. This is one of the three main subjects of the necessary level of education in Nigeria. It is expected that through it, students will achieve the national target of education. The most concern is how students see themselves in the light of the subject matter.

Students ' self-perception is one variable found by researchers, which could potentially influence social studies students ' academic performance. Self-perception, according to Pelvin and Rubin (2006), is referred to as a person's intentional or intentional interpretation of what he or she is. How the learner perceives the learning environment depends on how he or she interprets events in a particular environment or what the meaning of events appears to him or her.

The concept of self-perception is closely linked to

Edinyang, Sunday David, Associate Professor in the Department of Social Science Education, Faculty of Education, University of Calabar, Calabar, Cross River State, Nigeria.

Ushie, Doris Emmanuel, Assistant Lecturer in the Department of Social Science Education, Faculty of Education, University of Calabar, Calabar, Cross River State

Urubulam, Cecilia, Masters Degree Student with the Department of Social Science Education, Faculty of Education, University of Calabar, Cross River State, Nigeria self-concept- this is how the student sees himself or herself, particularly concerning the academic subject. In that context, the two concepts would be used interchangeably. Cruikshank (2007) stated that there is considerable evidence that children who have a lower level of self-perception in school or see themselves as less than their peers. The student self-concept is an essential component of academic performance assessment. This is because self-perception informs a person of his or her cognitive and emotional reactions to a task or situation.

Pajares and Valiante (2002) noted that self-perception provides context, structures, roles, processes, and expectations for perceiving, controlling, and assessing one's behaviour. Also, Pajares and valiant (2002) stressed that different aspects of students ' self-perception, such as self-efficacy, were closely linked to self-regulation of learning. In the same way, Brookover (2007) distinguished self-perception and academic capacity as one of several potential self-concepts. Thus distinction, according to Brookover, may allow the student to concentrate on some aspects of school life, which infringes directly on self-perception and academic performance. A related study by Barker (2008) indicates a positive relationship between self-perception and academic success. According to Barker, the greater the self-perception, the better and higher the results, and improvements in self-concept correlate with changes in performance.

Roggers (2006), based on observations received as a psychotherapist and research results, has come to consider self-perception as an significant determinant of educational achievement. William and Cole (1999) indicated that the self-perception of an person is an significant determinant as far as his academic performance is concerned. This means that if an person considers himself as intelligent and knowledgeable, it reflects in his academic pursuit. Similarly, if one finds oneself as stupid and inept, so life appears to work out.

Brookover, Thomas, and Paterson (2007) found in a student self-perception analysis that there is a strong, meaningful correlation between self-perception and academic performance, while scores of intelligence have been tracked. A successful student has a positive view of themselves. A healthy knowledge of oneself typically tends to be closely tied to personal development. This means the way a student sees himself/herself helps assess success or failure in his / her school.

Bills (2005) reveals in research analysis of 
self-perception and academic performance that there is a strong correlation between self-perception and academic success in the research, as he observed 100 high school students in Florida for six months and found that they perform better academically than students with a negative perception.

Olotu (2010) discovered that those with negative attitudes do not learn as much as those with positive attitudes in a comparative student test. The finding of Fitts (2009) indicates a close association between the self-perception of the students and their academic success. Fits noted negative attitudes have a declining effect on students. Fitts advised that to be able to perform well; students should be encouraged to develop a favorable attitude towards the subject.

Good (2006) indicates that proper nutrition and preserving the students' self-perception in a classroom is of considerable importance for their excellent and productive academic outcomes, as it influences the students' teachers' perceptions, and in turn, influences the teacher's relationship with the students. Good maintained stoutly that self-perception is an essential component of education, as a person relies on how he/she views him/herself as one that is likely to be successful. He/she tries harder for it, but if he/she considers him/herself as one who is likely to struggle, he/she becomes shy and withdrawn. Miller (2006) notes that motivation and performance are facets of self-perception. Miller also acknowledges that self-perception of the drive for success arises from perceptions and expresses itself in competition and comparisons. The competition allows one to understand oneself, discover one 's position, and strive to achieve, expect results, build passion through high goal efforts. And that one often gets feedback that, in turn, helps one by successful academic success to discover one's self-perception and motivation for achievement.

Nevertheless, Epstein (2007) noted that if a person sees himself as successful in achieving his goal, he experiences feelings of pride that promote the development of a positive self-perception. Theresa (1998) actively promoted a reluctance to mark children as messy or smart. Too often, the effect of such marking on the students is overlooked for Theresa. Theresa noted that these students often know this categorization, and while the excellent student is optimistic, the ineffective develops an inferiority-complex feeling and can not be matched with others. So the feeling of "self" should have a rewarding impact not just on the students' personality and academic achievement. Theresa (1998) believed that the institutions responsible for their education are interested in information about their personality and understanding the 'self' has. Blairs (2006) noted that the way a person sees himself and the kind of fears that he has are essential factors in deciding the things that he is seeking. Thus problems of negative self-perception are reflected by under-recipients in school and delinquency.

Ezewu (2007) helped to discover that a child with a positive attitude to what he knows is highly motivated to take part in activities that facilitate learning, creating a good self-perception of himself in relation to the entire world of teaching. Ezewu also argued that the quality of education results depends on the input factors and characteristics of learners identified in terms of attitude, self-perception, and habits of study. Therefore, Ezewu indicated that teachers should access the learner's attitudes of learners, encouragement, self-perception, and learning habits, not just to gain information from the textbooks. It inspired the researcher to study how students view themselves in their academic success in the Calabar Education Zone, Cross River State, Nigeria, as an influence on social studies.

\section{STATEMENT OF THE PROBLEM}

Student academic performance in social studies, both internally and externally, among junior high school students in Cross River State's Calabar Education Zone, has continued to decline steadily. Students who were sitting for the Junior School Certificate examination had a trend-low result. It's much worse for social-studies students taking interterminal or promotional tests. Education business stakeholders have drawn attention to the situation. The disease was attributed to the following factors related to schools by educators and researchers: lack of sufficient textbooks, lack of qualified teachers, insufficient facilities, poor teacher remuneration, and poor working attitudes. There has been little to no discussion of any of the factors that led to this. This led the researcher to determine if social studies success in Cross River's Calabar education zone was significantly related to variables such as self-perception.

\section{RESEARCH QUESTION}

To what extent do students' self-perception influence academic performance in social studies?

\section{Hypothesis}

$\mathrm{H}_{\mathrm{o}}$ There is no significant relationship between self-perception of students and their academic performance in social studies.

\section{METHODOLOGY}

The analysis adopted a survey research design. The design for this study was deemed appropriate as it collected data from the sample from which generalization was made to the population. The research target population consisted of all Junior Secondary School (JSS) class Social Studies students from specified schools in the Calabar State Cross River Education Region. This is because both of them offer social studies. Nonetheless, in the course of the study, only JSS 3 students caught attention. The decision to use students from JSS3 was based on their being the most knowledgeable and academically intelligent. Secondly, they are the study class planning for the transition to the higher secondary. In the area, the total number of JSS students was 15,000, five hundred and twenty-eight $(15,528)$. Nevertheless, as only students from JSS3 were involved in the study, review centered on a population of students from four thousand, seven and twenty-one (4721) social studies.

The research sample consisted of 500 students (about $10 \%$ of the population) randomly selected from the sampled schools in the state 's six local government zones. A simple random sampling technique was used to establish the range. The name of the schools in local government was written in a piece of paper from which samples were taken. Fifteen (15) 
schools were selected for research purposes (approximately 20 percent) out of 74 schools. For choosing students from selected schools, the same approach was used. Nonetheless, in this case, students were chosen randomly in the order/interval of five.

Two methods were used to collect the data. All were entitled: Student Self-Perception Questionnaire (SSPQ), and Performance Evaluation in Social Studies (SOSPT). The investigator developed the questionnaire with the vital help of two research experts. The questionnaire was an apparatus with 20 objects. Based on the same scale as Strongly Accepted (SA), Accepted (A), Disagreed (D), and Strongly Disagreed (SD), Each item allowed the respondent to respond to its various actions. Three research experts evaluated and validated the instrument, both in Social Studies and in Measurement and Evaluation. To determine the questionnaire's reliability, thirty respondents who were not part of the main sample were administered the 20 item instrument. The data obtained were used for calculating the instrument's reliability index using the Cronbach Alpha test. From this research, a reliability coefficient of 0.83 was obtained, which showed that the instrument was reliable and could be used for the study. The result of the reliability coefficient is listed in Table 1.

The SOSPT was a 20-item resource focused on the JSS3 curriculum. It had four choices, lettered A to D, from which the students were supposed to select one. The questions were also tested by researchers who are both professors of Social Studies at the University, and all have taught Social Studies in high schools.

Table 1:Cronbach alpha reliability of the instrument

$\begin{array}{lllll}\text { Variables } & \text { No. of Items } & x & \text { SD } & \begin{array}{c}\text { Crombach } \\ \text { Co-efficient }\end{array}\end{array}$

Self-Perception

\section{RESULTS}

Test of Hypothesis

The hypothesis of directing the study is:

$\mathrm{H}_{\mathrm{o}}$ : There is no significant relationship between students' self-perception and their academic performance in Social studies. It was tested at 0.05 level of significance using Pearson Product Correlation analysis. The result is presented in Table 2.

TABLE 2: Pearson Product moment correlation analysis of self-perception and students' academic performance (N=500)

\begin{tabular}{llllll}
\hline Variables & $\mathrm{N}$ & $\mathrm{X}$ & $\mathrm{SD}$ & r-cal & Sig. \\
\hline Self-perception & 500 & 18.43 & 2.39 & $0.41^{*}$ & 0.001 \\
$\begin{array}{l}\text { Academic } \\
\text { Performance }\end{array}$ & 500 & 13.56 & 2.10 & & \\
\hline
\end{tabular}

$\begin{array}{lll}18.43 & 2.39 & 0.83\end{array}$

The outcome of the study provided in Table 2 indicates that the measured $r$ of 0.41 is higher than the relevant level of 0.001 at a 0.05 significance level and 498 degrees of freedom. This means the relationship was significant. And the study rejected the null hypothesis. And there is a vital connection in social studies between self-perception and student academic success.
The Pearson coefficient $\left(\mathrm{r}_{0.41}\right)$ signifies a medium positive relationship, meaning that a positive self-perception would result in high academic performance. Conversely, a negative self-perception would bring about low academic performance.

\section{A.DISCUSSION OF FINDINGS}

The data analysis results presented in Table 2 showed that the respondents accepted that all things in Table 1 were social studies' self-perceptions related to their academic success. The study results were consistent with the findings of Brookover, Thomas, and Paterson (2007) whose research on student self-perception showed that there is a positive and significant correlation between student self-perception, showing that there is a positive and significant correlation between self-perception and academic success, even though intelligence scores were controlled. A good student ultimately views himself in a meaningful way. Good self-perception usually tends to be closely tied to personal improvement. It means how a person sees himself helps to assess his / her success or failure at school.

The results of this research were also consistent with the findings of Bills (2005), whose analysis of the relationship between student self-perception and academic performance reveals that a clear association existed between student self-perception and academic performance when he researched and discovered 100 high school students in Florida for six months;

Besides, the findings of this study have confirmed Fitts' (2009) results, the finding of which shows that there is a near correlation between students' self-perception and their academic achievement. Fits noted that a negative attitude has a downward influence on students. Fitts advise that for students to perform well, they need to be motivated to cultivate a favorable attitude toward the subject.

\section{CONCLUSION AND RECOMMENDATION}

Based on the results of this research, it was revealed that low student self-perception significantly relates to students ' academic performance in social studies. Positive self-perception brings in strong academic success and vice 
versa,

Based on these results, the recommendation is made as follows:

Teachers of social studies should cultivate positive attitudes towards students as this will promote successful participation in classroom instruction. If students voluntarily engage in classroom discussions, they will not be discouraged by being scolded or booed for making mistakes or providing the wrong answers. This would improve students' positive self-perception.

\section{REFERENCES}

[1] Barker, E. (2008). Psychology applied to learning. New York: Atlantic Houghton, Mifflin Company.(P.19-26).

[2] Bills, E. R. (2000). A system for assessing effectiveness. Alabama; University Press, (P.37-49)

[3] Blair, G. M. (2006) The role of the teachers in a researched-based system. Educational Media International. 2(4), 118.

[4] Brookover, S. (2007). The Science of Learning and the art of teaching. Harvard Educational Review, 20(24), 86-97.

[5] Brookover, S., Thomas, U., \& Paterson, O. (2007). Social attitude of pupils in schools: Handbook Of research on teaching. Chicago: Rand McNally and Co. (P. 41-49)

[6] Burton, J. A. (2005). Relationship of discrete classroom behaviours to fourth-grade achievement. Journal of Educational Psychology. 4(3), 74-80.

[7] Cross River State statistics Department of post-primary education Board 2007 (CRSSDPPEB). (P. 5-7)

[8] Cruikshank, D.R. (2007). Reflective teaching as a strategy for teacher growth. Educational Leadership. 32(38), 553-555

[9] Edeburn, B. S. \& Landry, T. (2005). Sexism in elementary school mathematics. The Elementary School Journal, 70(78), 275-277.

[10] Epstain, I. S. (2007) Gender difference in cognition: A function of maturation role? Science, 195(191), 572-573.

[11] Ezewu E. E. (2007) Social psychological factors of human learning in schools, Onitsha: Roadway Books Ltd.

[12] Fitts, I. (2009). Effects of gender role identification upon problem-solving. Journal of Abnormal and Social Psychology, 55(15), 208-212.

[13] Mccanless, O. S. (2008). Principles and practice of education. London: Longman group limited. (P. 47-56)

[14] Musen, R. (2007). Relationship between intelligence, scholastic motivation, and academic achievement. Psychological Report, 4(30), 3-8.

[15] Olotu, N. O. (2010). Psychology for the classroom. London: Methuen Publishers. (P. 91-116).

[16] Pajares, S. \& Valiante, J. S. (2002). Effects of an advanced organizer on students differing in pre-requisite skills and knowledge. Unpublished Ph.D. Dissertation, Oklahoma State University. (P. 36-42)

[17] Pervin, U. \& Rubbin, L. (2006). A guide to teaching practice. London: Stafford Montrreuil Co. (P.36-42).

[18] Roberts, R. (2007). Does class size matter? The National Elementary Principal, 50 (57), 78-81.

[19] Roggers, W. L. (2006). Facilitating student learning: An introduction to educational psychology, New York: Harper and Row Publishers. (P. 63-79).

[20] Schunk, E. T. \& Ertmer, b. (2002). The precepts of good teaching: The Clearinghouse. New York: Harleign Dickson University Press. (P. 73-77)

[21] Theresa, S. (2008). Stability and flexibility in teaching, Teaching and Teacher Education, 4(3), 33-38.

[22] Walcott, O., Beathy, T., \& Clark, R. (20080. The role of teachers in a researched-based system. Educational Media International, 2(4), 118.

[23] Williams, D., \& Cole, S. (2009). Growth in mathematics skills during the intermediate years: Sex differences and school effects. Review of Educational Research. 14(3). 157-174.

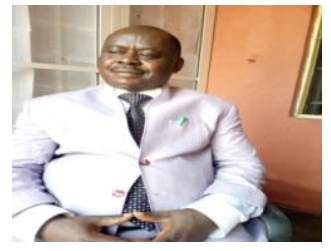

First Author: Edinyang, Sunday David, Is an Associate Professor in the Department of Social Science Education, Faculty of Education, University of Calabar, Calabar, Cross River State, Nigeria. He was a one time coordinator of Environment Education at the University of Calabar, also one time Post Graduate School Representative at the Department of Social Science Education, He is currently the head of Department of The Department of Social Science Education. He is form Nsit Atai Local Government of Akwa Ibom State, Nigeria. He got his Bachelor in Education Political Science degree from the University of Calabar, he also got his master degree and Ph.D. in Social Studies from the the same University. He is happily married and the marriage is blessed with six children (three boys and three girls). He is a prolific writer who has published several books and article as can be seen on his google scholar profile: https://scholar.google.com/citations?user=9gyvGaMAAAAJ\&hl=en.

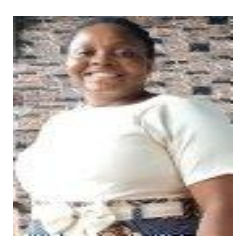

Second Author: Ushie, Doris Emmanuel, is an Assistant Lecturer in the Department of Social Science Education, Faculty of Education, University of Calabar, Calabar, Cross River State. She a Bachelor in Education Social Studies degree and Masters in Social Studies from the same department She has co-authored several article as can be seen on her google scholar page:

https://scholar.google.com/citations?hl=en\&user=DcYqk0MAAAAJ.

Urubulam, Cecilia Is a Masters Degree Student with the Department of Social Science Education, Faculty of Education, University of Calabar, Cross River State, Nigeria. 